\title{
Generation of Functional Hepatic Cells from Pluripotent Stem Cells
}

\section{Songyan Han\#, Alice Bourdon\#, Wissam Hamou, Noelle Dziedzic, Orit Goldman and Valerie Gouon-Evans*}

Department of Developmental and Regenerative Biology, Black Family Stem Cell Institute, Mount Sinai School of Medicine, New York, New York, USA ${ }^{\#}$ Authors contributed equally

\begin{abstract}
Liver diseases affect millions of people worldwide, especially in developing countries. According to the American Liver Foundation, nearly 1 in every 10 Americans suffers from some form of liver disease. Even though, the liver has great ability to self-repair, in end-stage liver diseases including fibrosis, cirrhosis, and liver cancer induced by viral hepatitis and drugs, the liver regenerative capacity is exhausted. The only successful treatment for chronic liver failure is the whole liver transplantation. More recently, some clinical trials using hepatocyte transplantation have shown some clinical improvement for metabolic liver diseases and acute liver failure. However, the shortage of donor livers remains a life-threatening challenge in liver disease patients. To overcome the scarcity of donor livers, hepatocytes generated from embryonic stem cell or induced pluripotent stem cell differentiation cultures could provide an unlimited supply of such cells for transplantation. This review provides an updated summary of hepatic differentiation protocols published so far, with a characterization of the hepatic cells generated in vitro and their ability to regenerate damaged livers in vivo following transplantation in pre-clinical liver deficient mouse models.
\end{abstract}

Keywords: Hepatic cells; Pluripotent stem cells; Embryonic stem cells

\section{Introduction}

The liver is a remarkable regenerative organ that can restore normal mass and function after an injury or partial hepatectomy. After mild injury, this ability is supported by the proliferation of fully mature hepatocytes, biliary epithelial cells [1] as well as the proliferation and help of surrounding cells including stellate cells, endothelial sinusoidal cells [2] and macrophages [3]. After severe injury or chronic disorder, hepatic progenitors or "oval cells-ductular hepatocytes" are recruited to ensure regeneration of the hepatocytic and biliary cell mass [1]. However, in end-stage liver diseases, such as fibrosis, cirrhosis, or liver cancer induced by viral hepatitis or drugs, the regenerative capacity of the liver is exhausted. Consequently, liver diseases are becoming one of the most common causes of mortality all over the world, especially in developing countries. Until now, liver transplantation is the most successful treatment for patient with chronic liver failure $[4,5]$. Alternatively to the whole organ transplantation, hepatocyte transplantation has been recently used in clinical trials for the treatment of acute failure and life-threatening metabolic liver diseases [6-9]. Unfortunately, these two options face the major concern of shortage of human donor livers [10]

To overcome the scarcity of donor livers, hepatocytes generated from pluripotent stem cell (PSC) differentiation cultures could provide an unlimited supply of such cells for transplantation in liver diseases. Embryonic Stem Cells (ESC) established from the inner cell mass of the blastocyst from early embryos or induced pluripotent stem cells (iPSC) from somatic adult cells are pluripotent, and proliferate indefinitely in an undifferentiated state in vitro $[11,12]$. Since the first establishment of mouse iPSC from embryonic fibroblasts by Takahashi and Yamanaka using viral vectors of Oct3/4, Sox2, Klf4 and c-Myc transcription factors, this technology has been widely and successfully applied to different species including human, established from different terminally differentiated adult cell types using various gene delivery systems (Recently discussed by Yamanaka, [13]).

Numerous studies summarized in this manuscript have shown that functional hepatocyte-like cells could be derived from ESCs (ESCHep) or induced pluripotent stem cells (iPSC-Hep), which express transcription factors and markers for mature hepatocytes as well as possess the metabolism and secretion functions both in vitro and in vivo (Table 1 and Table 2). Therefore, with their pluripotency and self-renewal abilities, ESCs and iPSCs have been proposed as a very valuable and unlimited transplantable hepatic cell source for patients with end-stage liver diseases [14]. The patient-specific iPSC-Hep have the advantage over the ESC-Hep to be immunologically compatible with the host for cell therapy approaches, and also to provide in vitro liver disease models [15]. As a proof of principle that iPSC can be a valuable source of functional hepatic cells, Espejel et al. [16] have injected iPSC into the blastocysts of the liver deficient Fah-/- mice, and found that by 70 days after birth, $100 \%$ of the hepatocytes in adult livers derived from the iPSC. These liver-chimeric mice display very healthy liver functions, demonstrating the definite ability of iPSC to generate functional hepatocytes in vivo avoiding the limitations of current in vitro differentiation protocols. Similar experiments were performed by Duncan's group by producing embryos by tetraploid complementation from mouse iPSC [17]. All embryos including their livers were derived from the iPSC except the extra embryonic tissues that were derived from the donor tetraploid embryos. The authors demonstrated that fetal mouse livers derived from iPSCs were indistinguishable from wildtype livers based on histological and gene expression assays, thereby supporting the ability of iPSCs to generate functional hepatocytes as ESCs do.

This review summarizes the results of various protocols using pluripotent stem cells published so far, and compares their efficiency in generating functional hepatic cells and their therapeutic relevance

*Corresponding author: Valerie Gouon-Evans, Department of Developmental and Regenerative Biology, Black Family Stem Cell Institute, Mount Sinai School of Medicine, New York, New York, USA, Tel: 212-241-4033; Fax: 646-5379695; E-mail: Valerie.gouon-evans@mssm.edu

Received July 06, 2012; Accepted August 13, 2012; Published August 15, 2012

Citation: Han S, Bourdon A, Hamou W, Dziedzic N, Goldman O, et al. (2012) Generation of Functional Hepatic Cells from Pluripotent Stem Cells. J Stem Cell Res Ther S10:008. doi:10.4172/2157-7633.S10-008

Copyright: (C) 2012 Han S, et al. This is an open-access article distributed unde the terms of the Creative Commons Attribution License, which permits unrestricted use, distribution, and reproduction in any medium, provided the original author and source are credited. 
Citation: Han S, Bourdon A, Hamou W, Dziedzic N, Goldman O, et al. (2012) Generation of Functional Hepatic Cells from Pluripotent Stem Cells. J Stem Cell Res Ther S10:008. doi:10.4172/2157-7633.S10-008

Page 2 of 11

\begin{tabular}{|c|c|c|c|c|c|c|c|c|c|}
\hline References & Species & $\begin{array}{l}\text { Protocol } \\
\text { specificity }\end{array}$ & $\begin{array}{c}\text { EB } \\
\text { monolayer }\end{array}$ & $\begin{array}{l}\text { Endoderm } \\
\text { induction }\end{array}$ & & $\begin{array}{c}\text { Hepatic } \\
\text { specification } \\
\text { and maturation }\end{array}$ & & $\begin{array}{l}\text { In vitro functional } \\
\text { assays }\end{array}$ & $\begin{array}{l}\text { In vivo } \\
\text { assay }\end{array}$ \\
\hline & & & & Inducers & $\begin{array}{c}\text { Efficiency \& } \\
\text { marker }\end{array}$ & Inducers & $\begin{array}{c}\text { Efficiency \& } \\
\text { marker }\end{array}$ & & \\
\hline \multicolumn{10}{|l|}{ Cytokines only } \\
\hline $\begin{array}{c}\text { Gouon-Evans et } \\
\text { al. [50] }\end{array}$ & mESC & & EB & Act & $\begin{array}{l}55 \% \text { Foxa2/ckit/ } \\
\text { Cxcr4 }\end{array}$ & $\begin{array}{l}\text { BMP4, bFGF, } \\
\text { HGF, Dex, TGFa, } \\
\text { EGF, VEGF }\end{array}$ & $\begin{array}{c}70 \% \text { Afp, } 60 \% \\
\text { Alb }\end{array}$ & Alb, Glycogen & yes \\
\hline Cai et al. [25] & hESC & & monolayer & Act, ITS & $80 \%$ Foxa2/Sox 17 & $\begin{array}{l}\text { FGF4 BMP2, } \\
\text { HGF, OSM, Dex }\end{array}$ & $70 \%$ Alb & $\begin{array}{l}\text { Alb, Glycogen, ICG, LDL, } \\
\text { p450 }\end{array}$ & yes \\
\hline Hay et al. [26] & hESC & & monolayer & Act, Wnt3a & & $\begin{array}{l}\text { Serum, Insulin, } \\
\text { HGF, OSM }\end{array}$ & up to $90 \%$ alb & $\begin{array}{l}\text { Urea, Gluconeogenesis, } \\
\text { Afp }\end{array}$ & yes \\
\hline $\begin{array}{c}\text { Agarwal et al. } \\
{[40]}\end{array}$ & hESC & & monolayer & $\begin{array}{l}\text { Act, low } \\
\text { serum }\end{array}$ & $72 \%$ Cxcr4 & FGF4, HGF & $70 \%$ & & yes \\
\hline $\begin{array}{l}\text { Basma et al. } \\
\text { [115] }\end{array}$ & hESC & & $\begin{array}{c}\text { EB } \\
\text { monolayer }\end{array}$ & Act, bFGF & & FGF, DMSO, Dex & $26 \%$ Asgr-1 & Alb, Urea, AAT, p450 & yes \\
\hline $\begin{array}{l}\text { Si-Tayeb et al. } \\
{[17]}\end{array}$ & hiPSC & & monolayer & Act & $80 \%$ & $\begin{array}{l}\text { BMP4, FGF2, } \\
\text { HGF }\end{array}$ & $80 \%$ & $\begin{array}{l}\text { Glycogen, LDL, Oil red O } \\
\text { storage, ICG, Urea }\end{array}$ & yes \\
\hline $\begin{array}{l}\text { Touboul et al. } \\
\text { [27] }\end{array}$ & hESC & & monolayer & $\begin{array}{l}\text { Act, FGF2, } \\
\text { BMP4, } \\
\text { LY294002 }\end{array}$ & $80 \%$ CXCR4 & $\begin{array}{c}\text { FGF10, RA, } \\
\text { SB431542, } \\
\text { FGF4, HGF, EGF }\end{array}$ & $\begin{array}{l}50-60 \% \mathrm{Hnf} 4 \alpha \\
\text { Afp or Ck19, } \\
35 \% \text { Asgr-1 }\end{array}$ & $\begin{array}{c}\text { Glycogen, p450, ICG, } \\
\text { LDL }\end{array}$ & yes \\
\hline $\begin{array}{l}\text { Ghodsizadeh et } \\
\text { al. [127] }\end{array}$ & hiPSC & & EB & Act & & $\begin{array}{l}\text { DMSO, HGF, } \\
\text { Dex }\end{array}$ & & $\begin{array}{l}\text { p450, Alb, Afp, Urea, } \\
\text { LDL. ICG, Glycogen, Oil } \\
\text { red O storage }\end{array}$ & \\
\hline $\begin{array}{l}\text { Mfopou et al. } \\
{[35]}\end{array}$ & hESC & & monolayer & $\begin{array}{l}\text { Act, Wnt3a, } \\
\text { low serum }\end{array}$ & $\begin{array}{l}60-80 \% \text { Cxcr } 4 / \\
\text { Foxa2 }\end{array}$ & $\begin{array}{c}\text { FGF10, BMP, } \\
\text { Cyclo, DAPT, } \\
\text { Exendin-4, IGF1, } \\
\text { HGF }\end{array}$ & $40-60 \%$ Afp & Urea, Glycogen & \\
\hline $\begin{array}{l}\text { Sullivan et al. } \\
\text { [34] }\end{array}$ & hiPSC & & monolayer & Act, Wnt3a & & $\begin{array}{c}\beta-M E, \text { DMSO, } \\
\text { Insuli, HGF, OSM }\end{array}$ & $70-90 \%$ Alb & $\begin{array}{l}\text { p450,Fibrinogen, } \\
\text { Fibronectin, } \\
\text { Transthyretin, Afp } \\
\text { secretion }\end{array}$ & \\
\hline Rashid et al. [31] & hiPSC & & monolayer & $\begin{array}{l}\text { Act, FGF2, } \\
\text { BMP4, } \\
\text { LY294002 }\end{array}$ & & Act, HGF, OSM & $83 \%$ Alb & $\begin{array}{c}\text { Alb, p450, Glycogen, } \\
\text { LDL }\end{array}$ & \\
\hline Liu et al. [41] & hiPSC & & monolayer & $\begin{array}{l}\text { Act, low } \\
\text { serum }\end{array}$ & $90 \%$ Cxcr 4 & $\begin{array}{l}\text { FGF4, HGF, } \\
\text { OSM, Dex }\end{array}$ & $90 \%$ Afp & Alb, p450 & yes \\
\hline Li et al. [119] & miPSC & & monolayer & Act, ITS & & $\begin{array}{l}\text { FGF4, HGF, } \\
\text { OSM, Dex }\end{array}$ & $\begin{array}{l}\sim 90 \% \text { Afp, } ~ \\
\quad 90 \% \text { Alb }\end{array}$ & LDL, Glycogen, p450 & yes \\
\hline Woo et al. [39] & $\begin{array}{l}\text { hESC/ } \\
\text { hiPSC }\end{array}$ & & EB & $\begin{array}{l}\text { LiCL, GSK- } \\
3 \text { inhibitor } \\
\text { (BIO), } \\
\text { Wnt3a }\end{array}$ & $35 \%$ Foxa2/Sox 17 & HGF, OSM, Dex & $\sim 69 \%$ Alb/Ck18 & Urea, Alb, Glycogen & yes \\
\hline $\begin{array}{l}\text { Pauwelyn et al. } \\
\text { [37] }\end{array}$ & mESC & & monolayer & $\begin{array}{l}\text { Act, Wnt3a, } \\
\text { low serum }\end{array}$ & & $\begin{array}{c}\text { FGF2, } \\
\text { BMP4,FGF8b, } \\
\text { FGF1, FGF4, } \\
\text { Follistatin }\end{array}$ & & $\begin{array}{l}\text { Alb, Urea, Glycogen, } \\
\text { p450 }\end{array}$ & \\
\hline $\begin{array}{l}\text { Sancho-Bru et } \\
\text { al. [36] }\end{array}$ & miPSC & & monolayer & $\begin{array}{l}\text { Act, Wnt3a, } \\
\text { low serum }\end{array}$ & $70 \%$ Foxa2 & $\begin{array}{l}\text { BMP4,FGF2, } \\
\text { FGF1, FGF4, } \\
\text { FGF8, HGF, } \\
\text { Follistatin }\end{array}$ & $30 \% \operatorname{Hnf} 4 \alpha$ & $\begin{array}{l}\text { Alb, Glycogen, Urea, } \\
\text { p450 }\end{array}$ & \\
\hline He et al. [113] & mESC & & $\begin{array}{c}\text { EB } \\
\text { monolayer }\end{array}$ & Act & $\begin{array}{l}75 \% \text { Cxcr } 4 / \text { ckit } \\
\text { (monolayer) }\end{array}$ & $\begin{array}{c}\text { BMP4, bFGF, } \\
\text { EGF, TGFa, } \\
\text { VEGF, HGF, Dex }\end{array}$ & $\begin{array}{c}31 \% \text { Alb } \\
\text { (monolayer) }\end{array}$ & $\begin{array}{c}\text { Alb, Ammonia, Glycogen, } \\
\text { LDL, ICG }\end{array}$ & yes \\
\hline Chen et al. [38] & hiPSC & & monolayer & $\begin{array}{c}\text { Act, Wnt3a, } \\
\text { HGF }\end{array}$ & $61-64 \%$ & OSM, Dex, ITS & & $\begin{array}{l}\text { p450, Urea, LDL, } \\
\text { Glycogen }\end{array}$ & yes \\
\hline \multicolumn{10}{|c|}{ Genetic modification } \\
\hline Kubo et al. [71] & mESC & Hex expression & EB & Act & & Hex, BMP4 & & Alb, Transferrin & \\
\hline $\begin{array}{l}\text { Inamura et al. } \\
{[69]}\end{array}$ & $\begin{array}{l}\text { hESC / } \\
\text { hiPSC }\end{array}$ & Hex expression & monolayer & $\begin{array}{l}\text { Act, bFGF, } \\
\text { Hex } \\
\text { expression }\end{array}$ & $46 \%$ & $\begin{array}{l}\text { BMP4, FGF4, } \\
\text { HGF, OSM, Dex }\end{array}$ & & p450 & \\
\hline $\begin{array}{l}\text { Takayama et } \\
\text { al. [70] }\end{array}$ & $\begin{array}{l}\text { hESC / } \\
\text { hiPSC }\end{array}$ & $\begin{array}{l}\text { Sox17 and Hex } \\
\text { expression }\end{array}$ & monolayer & $\begin{array}{l}\text { Act, Sox17 } \\
\text { and Hex } \\
\text { expression }\end{array}$ & $\begin{array}{l}67 \% \text { Cxcr } 4 / \text { ckit } \\
57 \% \mathrm{Hex}\end{array}$ & $\begin{array}{l}\text { BMP4, FGF4, } \\
\text { HGF, OSM, Dex }\end{array}$ & $50 \% \mathrm{p} 450$ & LDL, p450 & \\
\hline
\end{tabular}


Citation: Han S, Bourdon A, Hamou W, Dziedzic N, Goldman O, et al. (2012) Generation of Functional Hepatic Cells from Pluripotent Stem Cells. J Stem Cell Res Ther S10:008. doi:10.4172/2157-7633.S10-008

Page 3 of 11

\begin{tabular}{|c|c|c|c|c|c|c|c|c|c|}
\hline $\begin{array}{l}\text { Takayama et } \\
\text { al. [56] }\end{array}$ & $\begin{array}{l}\text { hESC / } \\
\text { hiPSC }\end{array}$ & $\begin{array}{l}\text { Sox17 and Hex } \\
\text { expression }\end{array}$ & monolayer & $\begin{array}{l}\text { Act, Sox17 } \\
\text { and Hex } \\
\text { expression }\end{array}$ & & $\begin{array}{l}\text { BMP4, FGF4, } \\
\text { HGF, OSM, Dex }\end{array}$ & $\begin{array}{l}80 \% \mathrm{p} 450,80 \% \\
\text { Asgr1, c-met } \\
\text { or Alb }\end{array}$ & $\begin{array}{l}\text { LDL, p450, ICG, } \\
\text { Glycogen, Metabolism- } \\
\text { mediated toxicity }\end{array}$ & \\
\hline \multicolumn{10}{|c|}{ Epigenetic modification } \\
\hline Hay et al. [79] & hESC & $\mathrm{NaBu}$ & monolayer & Act, $\mathrm{NaBu}$ & $70 \%$ Cxcr4 & $\begin{array}{l}\text { DMSO, HGF, } \\
\text { OSM, } 8.3 \% \\
\text { serum }\end{array}$ & $\begin{array}{c}71 \% \text { Alb, } 65 \% \\
\text { Hepar-1 }\end{array}$ & $\begin{array}{l}\text { Glycogen, generation } \\
\text { and secretion of plasma } \\
\text { proteins, p450 }\end{array}$ & \\
\hline Li et al. [78] & mESC & $\mathrm{NaBu}$ & monolayer & Act, $\mathrm{NaBu}$ & $\begin{array}{l}100 \% \text { Cxcr } 4,65 \% \\
\text { ckit, } 63 \% \text { Epcam }\end{array}$ & $\begin{array}{l}\text { BMP4, FGF2, } \\
\text { HGF, EGF, } \\
\text { TGFa, Dex }\end{array}$ & $\begin{array}{c}51 \% \text { Afp, } 62 \% \\
\text { Alb }\end{array}$ & ICG, Glycogen & yes \\
\hline Duan et al. [57] & hESC & $\mathrm{NaBu}$ & monolayer & Act, $\mathrm{NaBu}$ & $\begin{array}{l}85 \% \text { Cxcr } 4 \text {, Sox } 17 \\
\text { and Foxa2 }\end{array}$ & $\begin{array}{l}\text { HGF, BMP2, } \\
\text { FGF4, BMP4, } \\
\text { DMSO, serum, } \\
\text { OSM, Dex }\end{array}$ & $90 \%$ Alb & ICG, Drug matabolism & \\
\hline Ren et al. [74] & mESC & $\mathrm{NaBu}$ & EB & $\mathrm{NaBu}$ & & HGF, Dex & $50 \%$ & Glycogen & \\
\hline \multicolumn{10}{|l|}{ Scaffold } \\
\hline Fang et al. [100] & mESC & $\begin{array}{l}\text { scaffold-alginate } \\
\text { microbeads }\end{array}$ & EB & FGFa & & $\begin{array}{l}\text { HGF, OSM, } \\
\text { Dex, Insulin, } \\
\text { Transferrin, } \\
\text { Selenium }\end{array}$ & $\begin{array}{l}49 \% \text { Alb, } 50 \% \\
\text { Ck18 }\end{array}$ & Alb, Urea & \\
\hline Li et al. [95] & mESC & $\begin{array}{l}\text { scaffold- } \\
\text { polyacrylamide } \\
\text { substrate }\end{array}$ & monolayer & DMSO & & $\begin{array}{l}\mathrm{NaBu}, \text { cells } \\
\text { placed on } \\
\text { polyacrylamide } \\
\text { substrate }\end{array}$ & $\begin{array}{l}70 \% \text { functional } \\
\text { hepatocyte-like } \\
\text { cells }\end{array}$ & Alb, Urea & \\
\hline $\begin{array}{l}\text { Mizumoto et al. } \\
{[97]}\end{array}$ & $\begin{array}{l}\text { mESC, } \\
\text { monkey } \\
\text { ESC }\end{array}$ & $\begin{array}{l}\text { scaffold-hollow } \\
\text { fibers }\end{array}$ & fibers & & & $\mathrm{NaBu}$ & & Ammonia, Alb & \\
\hline $\begin{array}{l}\text { Matsumoto et } \\
\text { al. [93] }\end{array}$ & mESC & $\begin{array}{c}\text { 3d scaffold- } \\
\text { Polyurethane Foam }\end{array}$ & EB & & & $\begin{array}{l}\text { aFGF, HGF, } \\
\text { OSM, Dex, ITS }\end{array}$ & & Glycogen, Ammonia, Alb & \\
\hline Lee et al. [94] & mESC & \begin{tabular}{|c|} 
Fibronectin / \\
collagen1, collagen \\
4 / laminin \\
\end{tabular} & monolayer & & & & & & \\
\hline $\begin{array}{l}\text { Farzaneh et al. } \\
\text { [99] }\end{array}$ & hESC & $\begin{array}{l}\text { scaffold-ultraweb } \\
\text { nanofiber }\end{array}$ & monolayer & Act & $\begin{array}{l}86 \% \text { Foxa2, } 94 \% \\
\text { Sox } 17,92 \% \text { Cxcr4 }\end{array}$ & $\begin{array}{c}\text { FGF4, } \\
\text { HGF,OSM, Dex }\end{array}$ & $66 \%$ Afp & $\begin{array}{c}\text { Afp, Alb, Urea, LDL, } \\
\text { Glycogen, ICG, PROD } \\
\text { activity }\end{array}$ & \\
\hline $\begin{array}{l}\text { Shiraki et al. } \\
\text { [128] }\end{array}$ & $\begin{array}{l}\text { miPSC/ } \\
\text { hESC }\end{array}$ & scaffold & monolayer & Act, bFGF & $\begin{array}{l}\text { 40\% Cxcr4 / E-cad } \\
\text { (mouse) }\end{array}$ & $\begin{array}{l}\text { RA, Act, bFGF, } \\
\text { ITS-DMEM, Dex, } \\
\text { HGF, DMSO, NA, } \\
\text { AsP, Akt inhibitor } \\
\text { treated cells }\end{array}$ & $45 \%$ Alb & & \\
\hline Miki et al. [59] & hESC & $\begin{array}{c}\text { scaffold-hydrophilic } \\
\text { hollow } \\
\text { fiber microfiltration } \\
\text { membranes }\end{array}$ & monolayer & Act & & $\begin{array}{l}\text { FGF4, BMP2, } \\
\text { HGF, OSM, Dex }\end{array}$ & $30 \%$ Asgpr & $\begin{array}{c}\text { Alb, Ammonia, Glycogen, } \\
\text { p450 }\end{array}$ & \\
\hline $\begin{array}{l}\text { Haque et al. } \\
\text { [101] }\end{array}$ & mESC & $\begin{array}{l}\text { E-cadherin } \\
\text { substratum }\end{array}$ & monolayer & Act, bFGF & $\sim 55 \%$ & HGF, OSM, Dex & $92 \%$ Alb & Glycogen & \\
\hline $\begin{array}{l}\text { Amimoto et al. } \\
{[96]}\end{array}$ & $\begin{array}{l}\mathrm{mESC} / \\
\mathrm{miPSC}\end{array}$ & $\begin{array}{l}\text { cellulose triacetate } \\
\text { hollow fibers }\end{array}$ & fibers & & & $\begin{array}{l}\text { NaBu, Dex } \\
\text { OSM, ITS }\end{array}$ & & Ammonium, Alb & \\
\hline \multicolumn{10}{|c|}{ Co-culture or conditional medium } \\
\hline Cho et al. [84] & mESC & $\begin{array}{l}\text { Co-culture with rat } \\
\text { hepatocytes }\end{array}$ & monolayer & & & & & Urea & \\
\hline Zhao et al. [82] & $\begin{array}{l}\text { hESC, } \\
\text { primate } \\
\text { ESC }\end{array}$ & $\begin{array}{c}\text { Co-culture with STO } \\
\text { feeder cells }\end{array}$ & monolayer & Act & & $\begin{array}{l}\text { FGF4, BMP2, } \\
\text { HGF, OSM, Dex }\end{array}$ & $90 \%$ Afp & $\begin{array}{c}\text { Alb, Glycogen, ICG, LDL, } \\
\text { PROD activity }\end{array}$ & \\
\hline $\begin{array}{l}\text { Fukumitsu et } \\
\text { al. [88] }\end{array}$ & mESC & $\begin{array}{l}\text { Co-culture with } \\
\text { murine fetal liver } \\
\text { stromal cell line }\end{array}$ & monolayer & $\begin{array}{l}\text { Trans } \\
\text { retinoic } \\
\text { acid }\end{array}$ & & $\begin{array}{l}\text { HGF, bFGF, } \\
\text { Nicotinamide, } \\
\text { I-ascorbic acid } \\
\text { phosphate, ITS, } \\
\text { Dex, OSM }\end{array}$ & & Glycogen, Ammonia, Alb & \\
\hline Huang et al. [83] & $\begin{array}{l}\text { primate } \\
\text { ESC }\end{array}$ & $\begin{array}{c}\text { Co-culture with } \\
\text { human ESC-derived } \\
\text { fibroblast-like cells }\end{array}$ & monolayer & & & & & $\begin{array}{l}\text { Haptoglobin, Urea, Alb, } \\
\text { EROD, Glycogen, HBV } \\
\text { infection }\end{array}$ & \\
\hline $\begin{array}{c}\text { Tuleuova et al. } \\
{[89]}\end{array}$ & $\begin{array}{l}\text { mESC, } \\
\text { hESC }\end{array}$ & $\begin{array}{l}\text { Culture with protein } \\
\text { microarray matrices }\end{array}$ & monolayer & & & & & & \\
\hline Ishii et al. [87] & $\begin{array}{l}\text { mESC, } \\
\text { hESC }\end{array}$ & $\begin{array}{l}\text { Co-culture with } \\
\text { murine fetal liver } \\
\text { stromal cells and } \\
\text { mesenchymal cells }\end{array}$ & monolayer & Act & & HGF & & $\begin{array}{l}\text { Glycogen, Ammonia, } \\
\text { p450 }\end{array}$ & \\
\hline
\end{tabular}




\begin{tabular}{|c|c|c|c|c|c|c|c|c|}
\hline Yu et al. [81] & hESC & $\begin{array}{c}\text { Co-culture with } \\
\text { mitomycin treated } \\
\text { 3T3-J2 feeder cells }\end{array}$ & EB & Act & & & & \\
\hline $\begin{array}{l}\text { Nishiofuku et } \\
\text { al. [90] }\end{array}$ & $\begin{array}{l}\text { mESC, } \\
\text { ratESC }\end{array}$ & $\begin{array}{c}\text { Co-culture with rat } \\
\text { hepatic stellate cells }\end{array}$ & EB & & & & & \\
\hline Han et al. [86] & mESC & $\begin{array}{l}\text { Co-culture with D4T } \\
\text { endothelial cells }\end{array}$ & $\begin{array}{c}\text { EB } \\
\text { monolayer }\end{array}$ & Act & $\begin{array}{c}\sim 50 \% \text { Foxa } 2 / \\
\text { Foxa3 }\end{array}$ & $\begin{array}{c}\text { EGF, TGF } \alpha, \text { Dex, } \\
\text { VEGF, bFGF, } \\
\text { HGF, BMP4 }\end{array}$ & $60 \%$ Afp, Alb & \\
\hline Pal et al. [80] & hESC & $\begin{array}{l}\text { Conditioned medium } \\
\text { from HepG2 cells }\end{array}$ & EB & bFGF & & & & $\begin{array}{c}\text { Glycogen, Afp, SGOT, } \\
\text { SGPT, GGT }\end{array}$ \\
\hline
\end{tabular}

Table 1: Summary of PSC-Hep differentiation protocols in serum free media.

PSC: pluripotent stem cell; Act: Activin A; NaBu: sodium butyrate; Afp: afp secretion; Alb: albumin secretion; LDL: low-density lipoprotein uptake; ICG: indocyanine green uptake; p450: cytochrome p450 activity; ammonia: ammonia metabolism; Urea: urea secretion and production; glycogen: glycogen storage (PAS staining); ASGPR: asiaglycoprotein receptor 1 ; ITS: Insulin, transferin, selenium.

in pre-clinical animal models of liver disease. The use of PSC-Hep for drug screening and liver disease models will not be discussed here.

\section{Hepatic Cell Generation from Pluripotent Stem Cells (PSC-Hep): The Embryonic Stem Cell-derived Hepatic Cells (ESC-Hep) and the Induced Pluripotent Stem Cell-derived Hepatic Cells (iPSC-Hep)}

In the last decade, numerous protocols have been established to generate ESC-Hep and iPSC-Hep. The most efficient and reproducible hepatic differentiation approaches are those that recapitulate in ESC and iPSC cultures the appropriate signalling pathways uncovered in embryo studies, thereby subsequently mimicking endoderm development, endoderm hepatic specification followed by hepatic cell maturation.

\section{Cytokine-based hepatic differentiation protocols}

The use of a specific cocktail of cytokines in a serum-free media became a pre-requisite to control in a timed manner the successive steps of liver organogenesis in differentiation cultures. Studies in Xenopus have demonstrated that different concentrations of the TGF $\beta$ (Transforming growth factor beta) family member, activin-A used as a surrogate for nodal, induce mesodermal and endodermal fates in animal cap cells in culture [18-23]. Consequently, since its first use in the mouse ESC cultures [24], high doses of Activin-A are now widely utilized for endoderm induction in ESC and iPSC cultures from human and mouse lines [25-31]. Associated with Activin-A, activation of other pathways has also been shown to promote endoderm development including FGF (Fibroblast growth factor) and Wnt signalings [26,27,29,32-39]. In some protocols, low doses of serum have been reported to be necessary for Activin-A to induce an efficient endoderm program $[30,40,41]$. The presence of PI3kinase inhibitor in the serum was suspected to be responsible for promoting Activin-A-induced endoderm development [42].

Originally, most of the ESC differentiations were performed using embryoid bodies (EBs), the three-dimensional structure that was meant to mimic the blastocyst and epiblast architecture [43,44]. Few years ago, D'Amour et al. [30] demonstrated efficient endoderm induction from monolayers of hESC that was subsequently reproduced by many groups. The monolayer induction is thought to better synchronize the endodermal cell fate by exposing the cells evenly to the endodermal inducer, Activin-A.

Regardless of the induction system used (EBs or monolayers), heterogeneity of endoderm cultures remains inherent to pluripotent stem cell differentiation cultures. To overcome this issue, Activin-Ainduced endoderm generated from pluripotent stem cell differentiation cultures have been enriched using the cell surface receptors CXCR4 [45], cKit [46], ENDM-1 [47], E-cadherin and PDGF receptor- $\alpha$ or through the selection of reporter molecules targeted to the Brachyury, Foxa2, Foxa3, goosecoid, sox17 and Hex loci [30,32,33,47-50]. Interestingly, endoderm induction appears to be always more effective in human cultures than in murine cultures, with the human endoderm fraction reaching $\sim 90 \%$ of the total population versus $\sim 60 \%$ at the most in murine cultures. The discrepancy of efficiency between both species may be due to the quicker endoderm induction in the mouse embryo compared to the human embryo, thereby restricting the time flexibility to modulate signaling to generate homogenous endoderm cell population in mPSC differentiation cultures. Overall, pluripotent stem cells have been successfully and reproducibly differentiated in serum-free media to endoderm with the help of Activin-A (Table 1).

To recapitulate the liver specification signaling based on developmental studies in the mouse and the Xenopus models [5155], many groups including ours have used the combination of BMPs (BMP2, BMP4) and FGFs (FGF1, FGF2, FGF4, FGF8, FGF10) to specify endoderm cells generated in pluripotent stem cell cultures $[17,25,27,28,35,36,40,50,56-59]$. Shh inhibition found in Xenopus to be required for hepatic and pancreas fate decision, has been shown to improve the generation of mESC-Hep with the use of cyclopamine [35]. In the same study, inhibition of Notch by DAPT also helped mESCHep development supposedly by favoring hepatocyte fate over the cholangiocyte fate [35]. Hepatocyte growth factor (HGF) is known to promote hepatoblast proliferation, migration and survival through its tyrosine kinase receptor c-Met $[60,61]$, and is therefore always used in PSC hepatic differentiation protocols. Following hepatic specification, combination of FGF10, retinoic acid and inhibition of Activin-A in the presence of SB431542 has been also reported to improve hepatic endoderm maturation [27]. Maturation of hepatoblasts in the mouse fetal liver requires Oncostatin M (OSM) secreted by hematopoietic cells [62]. Consequently, OSM has been also widely used in PSC hepatic cultures (Table 1).

\section{Genetic modification-based hepatic differentiation protocols}

The transcriptional machinery of the specified hepatic endoderm is very well documented including the homeodomain protein Mixer/ Mix.3 [63], the Sry-related HMG-box transcription factor Sox17 [64], the zinc-finger transcription factors Gata5, Gata4 and Gata6 [65,66], Hepatocyte nuclear factors HNF4a [67] and Hex [68]. Some studies have used this information to improve efficiency of hPSC-hep 
Citation: Han S, Bourdon A, Hamou W, Dziedzic N, Goldman O, et al. (2012) Generation of Functional Hepatic Cells from Pluripotent Stem Cells. J Stem Cell Res Ther S10:008. doi:10.4172/2157-7633.S10-008

Page 5 of 11

\begin{tabular}{|c|c|c|c|c|c|}
\hline Reference & Animal model & $\begin{array}{l}\text { Type and number of } \\
\text { transplanted cells }\end{array}$ & $\begin{array}{l}\text { Percentage of } \\
\text { repopulation }\end{array}$ & Improved liver functions & $\begin{array}{l}\text { Mouse survival after } \\
\text { transplantation }\end{array}$ \\
\hline Teratani et al. [118] & $\begin{array}{l}129 \times 1 / \mathrm{S} v \mathrm{~J} \text { and } \\
\text { BALB/c nude mice } \\
\text { (DMN, cirrhosis) }\end{array}$ & $\begin{array}{c}\text { mESC-Hep } \\
5 \text { e6/mouse (IV) }\end{array}$ & ND & $\begin{array}{l}\text { suppression of onset of fibrosis/cirrhosis } \\
\text { plasma fibrinogen } \\
\text { Alb }\end{array}$ & $\sim 40 \%$ after 12 weeks \\
\hline Heo et al. [116] & MUP-uPA/SCID + CCL4 & $\begin{array}{c}\text { mESC-Hep } \\
1 \text { e6/mouse (IS) }\end{array}$ & $\begin{array}{c}1.94 \%+/-5.81 \text { after } 82 \\
\text { days }\end{array}$ & 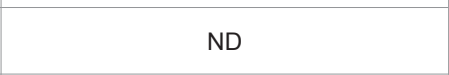 & ND \\
\hline $\begin{array}{l}\text { Gouon-Evans et al. } \\
{[50]}\end{array}$ & $\begin{array}{l}\text { Dpp4-/-, Rag2-/- (CCl4 } \\
\text { and retrorsine) and } \\
\text { Fah-/- }\end{array}$ & $\begin{array}{c}\text { mESC-Hep } \\
0.25-1.5 \text { e6/mouse } \\
\text { (IS) }\end{array}$ & $\begin{array}{c}\text { scattered endothelial and } \\
\text { hepatocitic clusters }\end{array}$ & ND & ND \\
\hline Agarwal et al. [40] & $\begin{array}{c}\mathrm{NOD} / \mathrm{SCID} \\
(\mathrm{CCl} 4 \text { and retrorsine, } \\
\text { acute liver failure })\end{array}$ & $\begin{array}{c}\text { hESC-Hep } \\
1 \text { e6/mouse (PV) }\end{array}$ & $\begin{array}{l}\text { sporadic hepatocytic } \\
\text { clusters }\end{array}$ & ND & ND \\
\hline Hay et al. [26] & NOD/SCID & $\begin{array}{c}\text { hESC-Hep } \\
1 \text { e6/mouse (IS) }\end{array}$ & $\begin{array}{l}\text { clusters of CK18/CK19 } \\
\text { and } \\
\text { Alb cells after } 3 \text { days in } \\
\text { the spleen }\end{array}$ & Alb & ND \\
\hline Cai et al. [25] & $\begin{array}{l}\text { SCID (CCl4 acute liver } \\
\text { failure })\end{array}$ & $\begin{array}{c}\text { hESC-Hep } \\
1 \text { e6/mouse (IS) }\end{array}$ & $\begin{array}{l}\text { scattered AAT human } \\
\text { cells in livers }\end{array}$ & ND & ND \\
\hline Duan et al. [121] & NOD/SCID & $\begin{array}{c}\text { hESC-Hep } \\
0.5 \text { e6/site (IH) }\end{array}$ & ND & Alb & ND \\
\hline Haridass et al. [114] & $\begin{array}{l}\text { Alb uPA, Rag2-/-, } \\
\text { IL2Rg-/- }\end{array}$ & $\begin{array}{c}\text { ES-Hep } \\
0.5-1 \text { e6/mouse (IS) }\end{array}$ & $\begin{array}{l}\text { few cells scattered } \\
\text { and teratoma formation }\end{array}$ & ND & ND \\
\hline Basma et al. [115] & $\begin{array}{l}\text { NOD/SCID (retrorsine } \\
\text { and } 50 \% \text { hepatectomy) } \\
\text { Alb-uPA SCID }\end{array}$ & $\begin{array}{c}\text { hES-Hep } \\
0.1-0.2 \text { e6/mouse (IS) } \\
\text { ASGPR+ cells }\end{array}$ & $\begin{array}{l}\text { few clusters of albumin+ } \\
\text { cells after } 28 \text { days }\end{array}$ & Alb, AAT & ND \\
\hline Li et al. [78] & Fah-/- & $\begin{array}{c}\text { mES-Hep } \\
1 \text { e6/mouse (IS) } \\
\text { ckit-Epcam+ day13 }\end{array}$ & $24 \%+-15 \%$ & ND & at least 10 weeks \\
\hline Touboul et al. [27] & $\begin{array}{l}\text { Alb uPA, Rag2-/-, } \\
\text { IL2Rg-/- }\end{array}$ & $\begin{array}{c}\text { hES-Hep } \\
0.5 \text { e6/mouse }(\mathrm{IH})\end{array}$ & $\begin{array}{l}\text { small and large clusters } \\
\text { throughout the liver } 8 \\
\text { weeks after injection. }\end{array}$ & Alb, AAT & ND \\
\hline Si-Tayeb et al. [17] & Fah-/- & $\begin{array}{c}\text { hiPSC-Hep } \\
0.3 \text { e6/mouse (IH) }\end{array}$ & ND & ND & ND \\
\hline Huang et al. [102] & Fah-/-, Rag2-/- & $\begin{array}{c}\mathrm{m} \text { iHep from fibroblasts } \\
0.833 \text { e6/mouse (IS) }\end{array}$ & $5 \%-80 \%$ & $\begin{array}{c}\text { ALT, AST, Tyrosine, Phenylalanine, } \\
\text { Bilirubin }\end{array}$ & $\begin{array}{l}5 / 12 \text { mice survived } \\
\text { after } 8 \text { weeks }\end{array}$ \\
\hline $\begin{array}{c}\text { Sekiya and Susuki } \\
{[103]}\end{array}$ & Fah-/- & $\begin{array}{c}m \text { iHep from fibroblasts } \\
\text { (IS) }\end{array}$ & large clusters & Bilirubin, ALT, ALP, Alb & $40 \%$ after 10 weeks \\
\hline Li et al. [119] & $\begin{array}{c}\text { BALB/c nude } \\
\text { (TAA, liver fibrosis) }\end{array}$ & $\begin{array}{c}\mathrm{m} \text { iPSC-Hep } \\
\sim 0.25 \text { e6/mouse (IV) }\end{array}$ & $\begin{array}{c}\text { scattered cells in the liver } \\
\text { after } 24 \text { hours }\end{array}$ & $\begin{array}{l}\text { ALT, AST, Bilirubin, Ammonia, } \\
\text { decreased ROS levels and necrosis }\end{array}$ & $\sim 80 \%$ after 14 days \\
\hline Chang et al. [117] & $\begin{array}{c}\text { BALBc nude } \\
(\mathrm{CCl} 4, \text { acute liver failure })\end{array}$ & $\begin{array}{c}\mathrm{m} \text { iPSC-Hep } \\
0.2-5 \text { e6/mouse (IP) }\end{array}$ & $\begin{array}{l}\text { Necrosis : } 70 \% \text { control, } \\
20 \% \text { transplant }\end{array}$ & ALT, AST, Bilirubin & $90 \%$ after 14 days \\
\hline Woo et al. [39] & $\begin{array}{c}\text { BALBc nude } \\
(\mathrm{CCl} 4, \text { acute liver failure })\end{array}$ & $\begin{array}{c}\text { hES-Hep / hiPSC-Hep } \\
2 \text { e6/mouse (IS) } \\
\text { ICG+ cells }\end{array}$ & $\begin{array}{l}\sim 20 \% \text { at day } 3 \text { versus } \\
\sim 10 \% \text { after } 35 \text { days }\end{array}$ & Alb & ND \\
\hline Chen et al. [38] & $\begin{array}{c}\text { NOD/SCID } \\
(\mathrm{CCl} 4, \text { acute liver failure })\end{array}$ & $\begin{array}{l}\text { hiPS -Hep } \\
\text { (IS) }\end{array}$ & ND & $\begin{array}{c}\text { rescue of hepatic necrosis; glutamyl } \\
\text { oxaloacetic aminotransferase; glutamyl } \\
\text { pyruvic aminotransferase; } \\
\text { Bilirubin; lactate dehydrogenase; } \\
\text { HepPar1; Alb }\end{array}$ & $5 / 7(71 \%)$ after 21 days \\
\hline Liu et al. [41] & NSG ( DMN, cirrhosis) & $\begin{array}{c}\text { iPSC-Hep } \\
0.1-2 \text { e6/mouse (IV) }\end{array}$ & $2 \sim 17 \%$ & Alb, CYP2E1 & $90 \%$ after 8 weeks \\
\hline He et al. [113] & Fah-/- & $\begin{array}{l}\text { mESC-Hep } \\
\text { (IS) }\end{array}$ & $\begin{array}{l}0.001 \%-12.5 \% \\
\text { after } 8-10 \text { weeks }\end{array}$ & $\begin{array}{c}\text { ALT, AST, Bilirubin, Alb, } \\
\text { succinylacetone, tyrosine and } \\
\text { phenylalanine secretion, } \\
30 \% \text { of wt FAH activity in recipients }\end{array}$ & $\begin{array}{l}8 / 20 \text { survived after } 2 \mathrm{nd} \\
\text { transplantation }\end{array}$ \\
\hline Bandi et al. [120] & $\begin{array}{c}\text { CD17.NOD/SCID } \\
(\text { Rif + Phen + MCT, acute } \\
\text { liver failure })\end{array}$ & $\begin{array}{c}\text { hESC-hep } \\
4-6 \text { e6/mouse } \\
\text { (IP with microcarriers) }\end{array}$ & $\begin{array}{c}\text { Detection of transplanted } \\
\text { cells in the peritoneal } \\
\text { cavity }\end{array}$ & $\begin{array}{c}\text { Endogeneous hepatocytes proliferation } \\
\text { Phenobarbital metabolism } \\
\text { Ammonium chloride }\end{array}$ & $\begin{array}{l}\text { 11/11 after } 14 \text { days } \\
\text { (MCT } 125, \text { mild injury) } \\
38 \% \text { after } 2 \text { weeks } \\
\text { (MCT } 160, \text { strong } \\
\text { injury) }\end{array}$ \\
\hline
\end{tabular}

PSC: pluripotent stem cell, IV: intra venous injection; IS: intra splenic injection; IH: intra hepatic injection; IP: intra peritoneal injection; hESC-MEC: hESC meso-endodermal cells. Detection in serum of Alb (Albumin), AAT (alpha 1 anti-trypsin), ALT (alanine aminotransferase), AST (aspartate aminotransferase), bilirubin, AP (Alkaline phosphatase) and CYP2E1 activity. 
generation by overexpression in a timely manner either Sox17, Hex and HNF4 $\alpha[56,69,70]$. Sox 17 and Hex were transduced into the hESCs and hiPSCs differentiation cultures at day 3 and day 6 of differentiation respectively to induce hepatic commitment. Adenovirus vectormediated overexpression of HNF4a in later cultures could further promote the hepatic maturation of the hPSC-Hep. Similarly, using a Hex inducible mESC line, Kubo et al. [71], have shown that forced expression of Hex in endoderm cells dramatically improved mESCHep hepatic specification and maturation synergistically with BMP-4.

\section{Epigenetic modification-based hepatic differentiation protocols}

In addition to genetic modulation, epigenetic modifications have been shown to improve hepatic differentiation protocols. For instance, sodium butyrate, a well-known specific HDACs inhibitor was used in ESCs and iPSC differentiation a long time ago [72]. In addition to decreasing cell death and promoting viability of ESCs, sodium butyrate has been reported to induce ESC differentiation toward different cell lineages including the neural cells [73], cardiac cells [29], pancreatic cells $[73,74]$, and hepatic cells [74-79]. Ren et al. [74], showed specifically that the cell fate induced by sodium butyrate depends on the concentration and time of the treatment. For instance, a low concentration of sodium butyrate with shorter exposure time induce generation of pancreatic progenitors over the hepatic progenitors, while higher concentrations with longer exposure favor the hepatic lineage fate

\section{Role of supportive cells and matrices in hepatic differentiation protocols}

To recapitulate the inductive signals established in liver embryogenesis in PSC hepatic differentiation cultures, some studies have proposed to combine the use of cytokines or chemicals with cocultures with supportive cells or cultures on specific matrices found in the developing liver. For instance, $\mathrm{Pal}$ et al. used conditioned media derived from the HepG2 liver carcinoma cell line during hESC differentiation, and obtained a high yield population of mature hESCHep that served as a functional in vitro hepatic cell model to study the effects of ethanol toxicity [80]. Fibroblast cells from different sources (STO feeder cells, 3T3 cells or ESC-derived fibroblast like cells) were utilized in several studies as supportive cells to improve hepatic differentiation of hESC as well as primate ESC and iPSC [81-83]. Huang et al. identified FGF2 and Activin A, as two factors secreted by the ESC-derived fibroblast important for endoderm induction. Additional source of hepatocytes harvested from rats in co-culture with mESC-derived cell cultures have been reported to improve mESC-Hep maturation [84]. Endothelial cells, mesenchymal cells, kupffer cells and stellate cells constitute the microenvironment of the developing hepatocytes, and were also reported to provide support for PSC-hep specification and maturation [85-90]. Our lab used an immortalized endothelial cell line derived from mESC cultures to improve mESCHep generation [86]. We demonstrated that endothelial cells are not only required for hepatic endoderm outgrowth as demonstrated previously by Zaret's group [91], but are also essential earlier to induce hepatic specification of endoderm through dual repression of Wnt and Notch signaling in endoderm cells [86]. This was one example of few studies showing that PSC differentiation cultures are not only a source of hepatic cells for future cell therapy, but also an in vitro culture system to understand liver organogenesis as much as embryology studies in animal models help improving PSC differentiation protocols.
Another alternative to produce better PSC-Hep in vitro is to use specific matrices or scaffold that would mimic the proper architecture of the in vivo microenvironment of the developing liver. Using an extracellular matrix microarray platform for the differentiation of mESC toward an early hepatic fate, Flaim et al. [92] have established combinations of extracellular matrices that synergistically impact both hepatic ESC differentiation and mESC-Hep hepatic functions. Specific studies have identified a wide variety of artificial materials and natural matrices to improve both human and mouse PSC-Hep generation such as collagen type I, vitrogen, matrigel, polyurethane foam [93], fibronectin, laminin [94], polyacrylamide [95], hollow fibers [59,96,97], poly-l-lactic acid plus polyglycolic acid [98], ultraweb nanofibers [99], alginate microbeads [100] and also recombinant E-cadherin substratum [101]. Compared to the $2 \mathrm{D}$ culture, the $3 \mathrm{D}$ scaffold system provides the physical support to enable spontaneous spheroid formation and mass cultivation of PSC-derived cells. With the support of the scaffold and cytokines, hepatocyte-like cells could be generated with the purity of up to $98 \%$ without cell isolation [101].

\section{Hepatic cell generation from direct reprogramming of fibroblasts}

Since the discovery of iPSC by Yamanaka in 2006, many groups have successfully reprogramed somatic cells directly to specialized cells bypassing the pluripotent stem cell stage. Last year, two studies have shown that fibroblasts can be reprogrammed directly to hepatic cells with the help of several transcription factors essential for liver development. Huang et al. [102] have demonstrated that the transduction of mouse fibroblasts from p19arf-/- mice with GATA4, FoxA3 and Hnf1 leads to the generation of hepatic cells that express hepatic markers, and restore liver functions following transplantation in the Fah liver deficient deficient mouse model. The second study from Sekiya et al. [103] used a different set of transcription factors, HNF4a, FoxA1 and FoxA2 or FoxA3 to reprogram mouse fibroblasts into hepatic cells, and demonstrated the in vivo ability of the cells to improve $40 \%$ of survival 10 weeks after cell transplantation in Fah deficient mice [103].

\section{In vitro characterization of the PSC-Hep}

To characterize the PSC-Hep in vitro, most of the above studies analyzed hepatic markers that are expressed in the early (alphafetoprotein, transthyretin) and later stages of liver maturation (albumin, cytokeratin 19 (CK19), CK7, CK18, cytochrome p450 enzymes (CyP), a1-antitrypsin (ATT), tyrosine aminotransferase (TAT), $\gamma$-glutamyltranspeptidase (GGT), glutathione $\mathrm{S}$ transferase (GST), tryptophan 2,3-dioxygenase (TDO), asialoglycoprotein receptor 1 (ASGPR), phosphoenolpyruvate carboxykinase (PPC), glucose-6-phosphatase (G6P), hepar-1 apolipoprotein F, fibrinogen, fibronectin, constitutive androstane receptor (Table 1). In addition to marker expression analyses supporting the differentiation stages, functional in vitro assays are also performed and usually compared to those from primary hepatocytes. Since liver exerts functions related to metabolism, protein synthesis, urea production and detoxification, the functional assays usually include albumin secretion, glycogen storage, low-density lipoprotein uptake, indocyanine green uptake and release, cytochrome $\mathrm{P} 450$ enzyme metabolism, urea production and metabolism-mediated toxicity. Results of these in vitro assays for each study are summarized in Table 1.

\section{Pre-clinical In vivo Relevance of PSC-Hep}

The definitive functional assay for PSC-Hep is their ability to 
regenerate diseased livers from animal models and ultimately to increase the animal survival rate. Chronologic studies of repopulation assays (summarized in Table 2) clearly indicate an improvement over the last years of pre-clinical relevance of the PSC-Hep. The differences between pre-clinical outcomes are the result of the combination of the intrinsic functionality of the PSC-Hep generated in vitro discussed above and the liver-deficiency animals used for each study.

To study the liver regenerative ability of the PSC-Hep in vivo, cells are transplanted into animal models in which the liver is injured to provide space for the transplanted cells and a proliferative stimulus for the regeneration to occur. Some of these models provide specific growth advantage for the transplanted cells. The liver injury models used in these studies include two genetic models, some chemical models and partial hepatectomy reviewed recently by Shafritz and Oertel [104].

The first genetic mouse model was established in 1991 by Sandgren et al. [105] by overexpressing the transgene urokinase type plasminogen activator under the albumin promoter (Alb-uPA mice). In this mouse model, uPA is expressed strictly in hepatocytes and appeared to be highly cytotoxic for these cells. Most of the uPA is secreted in serum, however a small amount remains in the liver resulting to intense liver damage. Consequently, most of the newborns die from hemorrhaging between 4 and 6 week-of-age, the rest of the newborns survive from extensive liver toxicity due to clonal growth of revertant hepatocytes that lost the transgene. Rhim et al. have subsequently tested the ability of the Alb-uPA mice to host transplanted normal hepatocytes [106]. They demonstrated that Alb-uPA mice provide a growth advantage to transplanted cells over the dying endogenous uPA expressing hepatocytes, and hence offer a permissive environment for survival, expansion and function of transplanted hepatocytes. Alternatively, Sandgren's group has developed another transgenic mouse model expressing uPA under the major urinary protein (MUP) promoter in which uPA expression was initiated in hepatocytes only from 2 to 4 week-of-age, thereby preventing the uPA-mediated neonatal lethality [107].

The second genetic mouse model, the fumarylacetoacetate hydrolase deficient mice (Fah-/-mice), was created by Grompe et al. [108] in 1995 to recapitulate the hereditary tyrosinemia type 1 (HT1) in human characterized by mutation in the Fah gene. The lack of the Fah enzyme, which is involved in the tyrosine catabolism pathway, induces an accumulation in hepatocytes of toxic metabolites including fumarylacetoacetate (FAA), leading to chronic liver damage. Accumulation of FAA can be prevented by adding in drinking water the chemical agent NTBC (2-(2-nitro-4-fluoromethylbenzoyl)-1,3cyclohexanedione) that is used in clinical settings to treat HT1 patients [108]. NTBC stops the tyrosine catabolism pathway upstream of the Fah enzyme, blocking the accumulation of FAA, thus preventing liver cell toxicity.

Therefore, the liver injury in Fah deficient mice can be easily controlled by the NTBC intake and removal. Overturf et al. [109] have shown that transplanted wild type hepatocytes have a growth advantage, and hence are able to repopulate mutant livers and restore liver functions. More recently, both the Fah deficient mice and AlbuPA transgenic mice have been crossed to the immunosuppressed mouse models Rag2-/-, Il2R $\gamma$-/- mice or the SCID mice (for AlbuPA) to allow liver repopulation by human hepatocytes and mouse hepatocytes harboring any genetic background [110-112].

These 2 genetic deficient liver mouse models provide not only liver injury but also selective growth advantage for transplanted human and mouse hepatocytes generated from pluripotent stem cells (27,50,78,113-116). Among those studies, Li et al. [78] demonstrated extensive liver repopulation capacity $(24 \%+/-15 \%)$ of purified mESCHep based on EpCAM expression (and negative for cKit) 10 weeks following transplantation in Fah-/- mice. Percentage of repopulation from PSC-Hep varied from $1.94 \%+/-5.81$ in MUP-uPA treated with CCl4 at 82 days [116], or 0.001\%-12.5\% in Fah-/- mice at 8 weeks [113], to detection of few clusters of transplanted cells in either Fah deficient mouse model [50] or uPA transgenic mouse model [27,114,115]. Two interesting studies describing the direct conversion of mouse fibroblasts by transducing a specific set of hepatic transcription factors demonstrated a remarkable ability of these cells to repair the damaged livers from Fah-/- mice [102,103].

The chemical liver injuries used to test the in vivo functionality of PSC-Hep include the carbon tetrachloride (CCl4)-induced hepatic centrilobular necrosis $(38,39,117)$, the dimethylnitrosamine (DMN)induced chronic cirrhotic injury [41,118] and the thioacetamide (TAA)-induced hepatic fibrosis [119]. The acute liver injury induced by $\mathrm{CCl} 4$ has recently been shown to be a successful mouse model to allow high liver repopulation ability of mouse [117] and human [38,39] PSC-Hep. Transplantation of miPSC-Hep or hPSC-Hep in the CCl4treated BALBc-nude mice reduced hepatic necrotic area, oxidative stress, and improved hepatic functions and the survival rate [117], and in a different study, regenerate about $10 \%$ of the liver mass 35 days after transplantation [39]. Similarly, Chen et al. [38] have successfully rescued the acute liver injury induced by $\mathrm{CCl} 4$ in NOD/SCID mice following transplantation of hiPSC-Hep. Another acute liver injury was developed by Bandi et al. [120] using a combination of the hepatotoxic drugs rifampicin and phenytoin that inhibit host hepatocyte proliferation followed by injection of monocrotaline, a pyrrolizidine alkaloid agent which induces sinusoidal endothelial cell injury to facilitate transplanted cell engraftment. This regiment produced 50$70 \%$ liver necrosis in NOD-SCID mice with $90-100 \%$ mortality over 2 weeks. Transplantation of hESC-derived meso-endodermal cells (hESC-MEC) intraperitoneally in this acute liver failure mouse model rescued the survival rate 2 weeks following surgery although further hepatic maturation of hESC-MEC was not successful [120].

Another variable parameter to consider when investigating the regenerative ability of PSC-Hep is the mode of cell delivery. Most of the published studies use the intra-splenic (IS) route to deliver PSCHep to the liver through the portal vein. These studies showed variable repopulation abilities of the transplanted cells, and in some cases partial rescue of the liver damage (38,39,50,78,113-116). Injections of cells through the portal vein deliver cells directly to the liver bypassing the spleen. Agarwal et al. [40] transplanted hESC-Hep through the portal vein of the $\mathrm{CCl}_{4}$ treated NOD/SCID, and showed some human cells integrated into the host liver. Cells can also be directly and locally targeted to the liver parenchyma or under the liver capsule. This mode of delivery is appropriate to newborn injection as the liver is visible through the skin. Few studies showed liver function improvement using this route $[17,27,121]$. The least invasive routes of delivery are intra-peritoneal (IP) and intra-venous (IV) injections.

Mostly, IP transplanted cells remain in the intra-peritoneal cavity [120] where they can still exert hepatic functions, even though one study has shown integration of the IP transplanted cells into the liver [117]. In the first study, cells were delivered IP with microcarriers that eventually revascularized in the peritoneal cavity and secreted proteins in blood circulation improving hepatic functions, and rescuing 100\% 
of animal survival 2 weeks after a mild injury and $38 \%$ after a stronger injury [120]. IV injections of PSC-Hep allowed integration of cells into the host livers and have shown some liver function improvement $[41,118,119]$.

\section{Conclusions}

In summary, the liver field of pluripotent stem cells has tremendously advanced the last decade with the generation in vitro of cells harboring hepatocytic functions and capable of improving some liver functions in vivo of mouse models with liver deficiency. Even though the hepatic differentiation protocols are presently very efficient and reproducible among different groups, the variability of hepatic differentiation efficiency between PSC lines remains unclear.

A recent publication from Yamanaka's group has shown that the variation in hepatic differentiation efficiency of hiPSCs was mostly due to donor differences [122] rather than the tissue from which the iPSCs were derived as indicated by other studies using mouse [123125] or human [126] tissues, or the iPSC derivation methods. This finding may impact our current vision of personalized medicine using hiPSC-Hep for liver functions rescue. In addition to differences in the propensity for hepatic differentiation among PSC lines, the consistency of the regenerative ability of PSC-Hep is still a challenge. Before the use of the PSC-Hep in clinical settings, many issues need to be resolved including namely the purity of the PSC-Hep cultures, the risk of teratoma development and the choice of delivery mode based on the liver damage. In addition to these technical limitations, there is a need to understand the interactions between the transplanted cells and the damaged microenvironment to improve PSC-Hep integration into the liver and their proliferation. One can suspect that some of these crosstalks are universal to all liver injuries, while some are specific to particular damages. Consequently, it is conceivable that understanding the response of the damaged microenvironment will help the generation of customized PSC-Hep to specific liver injuries.

\section{References}

1. Michalopoulos GK (2011) Liver regeneration: alternative epithelial pathways. Int J Biochem Cell Biol 43: 173-179.

2. Ding BS, Nolan DJ, Butler JM, James D, Babazadeh AO, et al. (2010) Inductive angiocrine signals from sinusoidal endothelium are required for liver regeneration. Nature 468: 310-315.

3. Boulter L, Govaere O, Bird TG, Radulescu S, Ramachandran P, et al. (2012) Macrophage-derived Wnt opposes Notch signaling to specify hepatic progenitor cell fate in chronic liver disease. Nat Med 18: 572-579.

4. Gilgenkrantz, H, Collin de l'Hortet A (2011) New insights into liver regeneration. Clin Res Hepatol Gastroenterol 35: 623-629.

5. Nguyen NT, Vierling JM (2011) Acute liver failure. Curr Opin Organ Transplant 16: 289-296.

6. Fox IJ, Chowdhury JR (2004) Hepatocyte transplantation. Am J Transplant: 7-13.

7. Hughes RD, Mitry RR, Dhawan A (2012) Current status of hepatocyte transplantation. Transplantation 93: 342-347.

8. Berry MN, Grivell AR, Grivell MB, Phillips JW (1997) Isolated hepatocytes-past, present and future. Cell Biol Toxicol 13: 223-233.

9. Puviani AC, Ottolenghi C, Tassinari B, Pazzi P, Morsiani E (1998) An update on high-yield hepatocyte isolation methods and on the potential clinical use of isolated liver cells. Comp Biochem Physiol A Mol Integr Physiol 121: 99-109.

10. Washburn K, Halff G (2011) Hepatocellular carcinoma and liver transplantation. Curr Opin Organ Transplant 16: 297-300.

11. Evans MJ, Kaufman MH (1981) Establishment in culture of pluripotential cells from mouse embryos. Nature 292: 154-156.
12. Takahashi K, Yamanaka S (2006) Induction of pluripotent stem cells from mouse embryonic and adult fibroblast cultures by defined factors. Cell 126 663-676.

13. Yamanaka S (2012) Induced pluripotent stem cells: past, present, and future. Cell Stem Cell 10: 678-684.

14. Sancho-Bru P, Najimi M, Caruso M, Pauwelyn K, Cantz T, et al. (2009) Stem and progenitor cells for liver repopulation: can we standardise the process from bench to bedside?. Gut 58: 594-603.

15. Colman A, Dreesen O (2009) Pluripotent stem cells and disease modeling. Cell Stem Cell 5: 244-247.

16. Espejel S, Roll GR, McLaughlin KJ, Lee AY, Zhang JY, et al. (2010) Induced pluripotent stem cell-derived hepatocytes have the functional and proliferative capabilities needed for liver regeneration in mice. J Clin Invest 120: 3120-3126.

17. Si-Tayeb K, Noto FK, Nagaoka M, Li J, Battle MA, et al. (2010) Highly efficient generation of human hepatocyte-like cells from induced pluripotent stem cells. Hepatology 51: 297-305

18. Green JB, Smith JC (1990) Graded changes in dose of a Xenopus activin A homologue elicit stepwise transitions in embryonic cell fate. Nature 347: $391-$ 394.

19. Green JB, New HV, Smith JC (1992) Responses of embryonic Xenopus cells to activin and FGF are separated by multiple dose thresholds and correspond to distinct axes of the mesoderm. Cell 71: 731-739.

20. Jones EA, Abel MH, Woodland HR (1993) The possible role of mesoderma growth factors in the formation of endoderm in Xenopus laevis. Dev Genes Evol 202: 233-239

21. Gamer LW, Wright CV (1995) Autonomous endodermal determination in Xenopus: regulation of expression of the pancreatic gene $\mathrm{XIHbox} 8$. Dev Bio 171: $240-251$.

22. McDowell N, Zorn AM, Crease DJ, Gurdon JB (1997) Activin has direct long range signalling activity and can form a concentration gradient by diffusion. Curr Biol 7: 671-681.

23. Ninomiya H, Takahashi S, Tanegashima K, Yokota C, Asashima M (1999) Endoderm differentiation and inductive effect of activin-treated ectoderm in Xenopus. Dev Growth Differ 41: 391-400.

24. Kubo A, Shinozaki K, Shannon JM, Kouskoff V, Kennedy M, et al. (2004) Development of definitive endoderm from embryonic stem cells in culture. Development 131: 1651-1662.

25. Cai J, Zhao Y, Liu Y, Ye F, Song Z, et al. (2007) Directed differentiation of human embryonic stem cells into functional hepatic cells. Hepatology 45: 1229 1239.

26. Hay DC, Fletcher J, Payne C, Terrace JD, Gallagher RC, et al. (2008) Highly efficient differentiation of hESCs to functional hepatic endoderm requires ActivinA and Wnt3a signaling. Proc Natl Acad Sci USA 105: 12301-12306.

27. Touboul T, Hannan NR, Corbineau S, Martinez A, Martinet C, et al. (2010) Generation of functional hepatocytes from human embryonic stem cells under chemically defined conditions that recapitulate liver development. Hepatology 51: 1754-1765.

28. Liu H, Ye Z, Kim Y, Sharkis S, Jang YY (2010) Generation of endoderm-derived human induced pluripotent stem cells from primary hepatocytes. Hepatology 51: 1810-1819.

29. Chen HP, Denicola M, Qin X, Zhao Y, Zhang L, et al. (2011) HDAC inhibition promotes cardiogenesis and the survival of embryonic stem cells through proteasome-dependent pathway. J Cell Biochem 112: 3246-3255.

30. D'Amour KA, Agulnick AD, Eliazer S, Kelly OG, Kroon E, et al. (2005) Efficient differentiation of human embryonic stem cells to definitive endoderm. Nat Biotechnol 23: 1534-1541.

31. Rashid ST, Corbineau S, Hannan N, Marciniak SJ, Miranda E, et al. (2010) Modeling inherited metabolic disorders of the liver using human induced pluripotent stem cells. J Clin Invest 120: 3127-3136.

32. Morrison GM, Oikonomopoulou I, Migueles RP, Soneji S, Livigni A, et al. (2008) Anterior definitive endoderm from ESCs reveals a role for FGF signaling. Cell Stem Cell 3: 402-415.

33. Gadue P, Huber TL, Paddison PJ, Keller GM (2006) Wnt and TGF-beta 
signaling are required for the induction of an in vitro model of primitive streak formation using embryonic stem cells. Proc Natl Acad Sci USA 103: 1680616811.

34. Sullivan GJ, Hay DC, Park IH, Fletcher J, Hannoun Z, et al. (2010) Generation of functional human hepatic endoderm from human induced pluripotent stem cells. Hepatology 51: 329-335.

35. Mfopou JK, Chen B, Mateizel I, Sermon K, Bouwens L (2010) Noggin, retinoids and fibroblast growth factor regulate hepatic or pancreatic fate of human embryonic stem cells. Gastroenterology 138: 2233-2245.

36. Sancho-Bru P, Roelandt P, Narain N, Pauwelyn K, Notelaers T, et al. (2011) Directed differentiation of murine-induced pluripotent stem cells to functional hepatocyte-like cells. J Hepatol 54: 98-107.

37. Pauwelyn K, Roelandt P, Notelaers T, Sancho-Bru P, Fevery J, et al. (2011) Culture of mouse embryonic stem cells with serum but without exogenous growth factors is sufficient to generate functional hepatocyte-like cells. PLoS One 6: e23096.

38. Chen YF, Tseng CY, Wang HW, Kuo HC, Yang VW, et al. (2012) Rapid generation of mature hepatocyte-like cells from human induced pluripotent stem cells by an efficient three-step protocol. Hepatology 55: 1193-1203.

39. Woo DH, Kim SK, Lim HJ, Heo J, Park HS, et al. (2012) Direct and indirect contribution of human embryonic stem cell-derived hepatocyte-like cells to liver repair in mice. Gastroenterology 142: 602-611.

40. Agarwal S, Holton KL, Lanza R (2008) Efficient differentiation of functional hepatocytes from human embryonic stem cells. Stem Cells 26: 1117-1127.

41. Liu H, Kim Y, Sharkis S, Marchionni L, Jang YY (2011) In vivo liver regeneration potential of human induced pluripotent stem cells from diverse origins. Sci Transl Med 3: 82ra39.

42. McLean AB, D'Amour KA, Jones KL, Krishnamoorthy M, Kulik MJ, et al. (2007) Activin a efficiently specifies definitive endoderm from human embryonic stem cells only when phosphatidylinositol 3-kinase signaling is suppressed. Stem Cells 25: 29-38.

43. Yamada T, Yoshikawa M, Kanda S, Kato Y, Nakajima Y, et al. (2002) In vitro differentiation of embryonic stem cells into hepatocyte-like cells identified by cellular uptake of indocyanine green. Stem Cells 20: 146-154

44. Jones EA, Tosh D, Wilson DI, Lindsay S, Forrester LM (2002) Hepatic differentiation of murine embryonic stem cells. Exp Cell Res 272: 15-22.

45. McGrath KE, Koniski AD, Maltby KM, McGann JK, Palis J (1999) Embryonic expression and function of the chemokine SDF-1 and its receptor, CXCR4. Dev Biol 213: 442-456.

46. Orr-Urtreger A, Avivi A, Zimmer Y, Givol D, Yarden Y, et al. (1990) Developmental expression of c-kit, a proto-oncogene encoded by the $W$ locus. Development 109: 911-923.

47. Gadue P, Gouon-Evans V, Cheng X, Wandzioch E, Zaret KS, et al. (2009) Generation of monoclonal antibodies specific for cell surface molecules expressed on early mouse endoderm. Stem Cells 27: 2103-2113.

48. Yasunaga M, Tada S, Torikai-Nishikawa S, Nakano Y, Okada M, et al. (2005) Induction and monitoring of definitive and visceral endoderm differentiation of mouse ES cells. Nat Biotechnol 23: 1542-1550.

49. Tada S, Era T, Furusawa C, Sakurai H, Nishikawa S, et al. (2005) Characterization of mesendoderm: a diverging point of the definitive endoderm and mesoderm in embryonic stem cell differentiation culture. Development 132 4363-4374.

50. Gouon-Evans V, Boussemart L, Gadue P, Nierhoff D, Koehler Cl, et al. (2006) BMP-4 is required for hepatic specification of mouse embryonic stem cellderived definitive endoderm. Nat Biotechnol 24: 1402-1411.

51. Crossley PH, Martin GR (1995) The mouse Fgf8 gene encodes a family of polypeptides and is expressed in regions that direct outgrowth and patterning in the developing embryo. Development 121: 439-451.

52. Jung J, Zheng M, Goldfarb M, Zaret KS (1999) Initiation of mammalian liver development from endoderm by fibroblast growth factors. Science 284: 19982003

53. Rossi JM, Dunn NR, Hogan BL, Zaret KS (2001) Distinct mesodermal signals, including BMPs from the septum transversum mesenchyme, are required in combination for hepatogenesis from the endoderm. Genes Dev 15: 1998-2009.
54. Wandzioch E, Zaret KS (2009) Dynamic signaling network for the specification of embryonic pancreas and liver progenitors. Science 324: 1707-1710.

55. Zhang W, Yatskievych TA, Baker RK, Antin PB (2004) Regulation of Hex gene expression and initial stages of avian hepatogenesis by Bmp and Fgf signaling. Dev Biol 268: 312-326.

56. Takayama K, Inamura M, Kawabata K, Katayama K, Higuchi M (2012) Efficient generation of functional hepatocytes from human embryonic stem cells and induced pluripotent stem cells by HNF4 $\alpha$ transduction. Mol Ther 20: 127-137.

57. Duan Y, Ma X, Zou W, Wang C, Bahbahan IS, et al. (2010) Differentiation and characterization of metabolically functioning hepatocytes from human embryonic stem cells. Stem Cells 28: 674-686.

58. Kim N, Kim H, Jung I, Kim Y, Kim D, et al. (2011) Expression profiles of miRNAs in human embryonic stem cells during hepatocyte differentiation. Hepatol Res 41: 170-183.

59. Miki T, Ring A, Gerlach J (2011) Hepatic differentiation of human embryonic stem cells is promoted by three-dimensional dynamic perfusion culture conditions. Tissue Eng Part C Methods 17: 557-568.

60. Kamiya A, Kinoshita T, Miyajima A (2001) Oncostatin M and hepatocyte growth factor induce hepatic maturation via distinct signaling pathways. FEBS Lett 492: 90-94.

61. Schmidt C, Bladt F, Goedecke S, Brinkmann V, Zschiesche W, et al. (1995) Scatter factor/hepatocyte growth factor is essential for liver development Nature 373: 699-702.

62. Kamiya A, Kinoshita T, Ito Y, Matsui T, Morikawa Y, et al. (1999) Fetal live development requires a paracrine action of oncostatin $M$ through the gp130 signal transducer. Embo J 18: 2127-2136

63. Henry GL, Melton DA (1998) Mixer, a homeobox gene required for endoderm development. Science 281: 91-96.

64. Hudson C, Clements D, Friday RV, Stott D, Woodland HR (1997) Xsox17alpha and -beta mediate endoderm formation in Xenopus. Cell 91: 397-405

65. Bossard P, Zaret KS (1998) GATA transcription factors as potentiators of gut endoderm differentiation. Development 125: 4909-4917.

66. Reiter JF, Alexander J, Rodaway A, Yelon D, Patient R, et al. (1999) Gata5 is required for the development of the heart and endoderm in zebrafish. Genes Dev 13: 2983-2995.

67. Ang SL, Wierda A, Wong D, Stevens KA, Cascio S, et al. (1993) The formation and maintenance of the definitive endoderm lineage in the mouse: involvement of HNF3/forkhead proteins. Development 119: 1301-1315.

68. Martinez Barbera JP, Clements M, Thomas P, Rodriguez T, Meloy D, et al (2000) The homeobox gene Hex is required in definitive endodermal tissue for normal forebrain, liver and thyroid formation. Development 127: 2433-2445.

69. Inamura M, Kawabata K, Takayama K, Tashiro K, Sakurai F, et al. (2011) Efficient generation of hepatoblasts from human ES cells and iPS cells by transient overexpression of homeobox gene HEX. Mol Ther 19: 400-407.

70. Takayama K, Inamura M, Kawabata K, Tashiro K, Katayama K, et al. (2011) Efficient and directive generation of two distinct endoderm lineages from human ESCs and iPSCs by differentiation stage-specific SOX17 transduction. PLoS One 6: e21780.

71. Kubo A, Kim YH, Irion S, Kasuda S, Takeuchi M, et al. (2010) The homeobox gene Hex regulates hepatocyte differentiation from embryonic stem cell-derived endoderm. Hepatology 51: 633-641.

72. Kretsovali A, Hadjimichael C, Charmpilas N (2012) Histone deacetylase inhibitors in cell pluripotency, differentiation, and reprogramming. Stem Cells Int 2012: 184154.

73. McKiernan E, O'Driscoll L, Kasper M, Barron N, O'Sullivan F, et al. (2007) Directed differentiation of mouse embryonic stem cells into pancreatic-like or neuronal- and glial-like phenotypes. Tissue Eng 13: 2419-2430.

74. Ren M, Yan L, Shang CZ, Cao J, Lu LH (2010) Effects of sodium butyrate on the differentiation of pancreatic and hepatic progenitor cells from mouse embryonic stem cells. J Cell Biochem 109: 236-244.

75. Zhou QJ, Xiang LX, Shao JZ, Hu RZ, Lu YL, et al. (2007) In vitro differentiation of hepatic progenitor cells from mouse embryonic stem cells induced by sodium butyrate. J Cell Biochem 100: 29-42. 
76. Rambhatla L, Chiu CP, Kundu P, Peng Y, Carpenter MK (2003) Generation of hepatocyte-like cells from human embryonic stem cells. Cell Transplant 12 : $1-11$.

77. Sharma NS, Shikhanovich R, Schloss R, Yarmush ML (2006) Sodium butyratetreated embryonic stem cells yield hepatocyte-like cells expressing a glycolytic phenotype. Biotechnol Bioeng 94: 1053-1063.

78. Li F, Liu P, Liu C, Xiang D, Deng L, et al. (2010) Hepatoblast-like progenitor cells derived from embryonic stem cells can repopulate livers of mice. Gastroenterology 139: 2158-2169.e8.

79. Hay DC, Zhao D, Fletcher J, Hewitt ZA, McLean D, et al. (2008) Efficient differentiation of hepatocytes from human embryonic stem cells exhibiting markers recapitulating liver development in vivo. Stem Cells 26: 894-902.

80. Pal R, Mamidi MK, Das AK, Gupta PK, Bhonde R (2012) A simple and economical route to generate functional hepatocyte-like cells from hESCs and their application in evaluating alcohol induced liver damage. J Cell Biochem 113: $19-30$.

81. Yu YD, Kim KH, Lee SG, Choi SY, Kim YC, et al. (2011) Hepatic differentiation from human embryonic stem cells using stromal cells. J Surg Res 170: e253-e261.

82. Zhao D, Chen S, Cai J, Guo Y, Song Z, et al. (2009) Derivation and characterization of hepatic progenitor cells from human embryonic stem cells. PLoS One 4: e6468.

83. Huang HP, Yu CY, Chen HF, Chen PH, Chuang CY, et al. (2010) Factors from human embryonic stem cell-derived fibroblast-like cells promote topologydependent hepatic differentiation in primate embryonic and induced pluripotent stem cells. J Biol Chem 285: 33510-33519.

84. Cho CH, Parashurama N, Park EY, Suganuma K, Nahmias Y, et al. (2008) Homogeneous differentiation of hepatocyte-like cells from embryonic stem cells: applications for the treatment of liver failure. FASEB J 22: 898-909.

85. Soto-Gutiérrez A, Navarro-Alvarez N, Zhao D, Rivas-Carrillo JD, Lebkowski J, et al. (2007) Differentiation of mouse embryonic stem cells to hepatocyte-like cells by co-culture with human liver nonparenchymal cell lines. Nat Protoc 2: 347-335.

86. Han S, Dziedzic N, Gadue P, Keller GM, Gouon-Evans V (2011) An endothelial cell niche induces hepatic specification through dual repression of Wnt and Notch signaling. Stem Cells 29: 217-228.

87. Ishii T, Yasuchika K, Fukumitsu K, Kawamoto T, Kawamura-Saitoh M, et al. (2010) In vitro hepatic maturation of human embryonic stem cells by using a mesenchymal cell line derived from murine fetal livers. Cell Tissue Res 339: 505-512.

88. Fukumitsu K, Ishii T, Yasuchika K, Amagai Y, Kawamura-Saito M, et al. (2009) Establishment of a cell line derived from a mouse fetal liver that has the characteristic to promote the hepatic maturation of mouse embryonic stem cells by a coculture method. Tissue Eng Part A 15: 3847-3856.

89. Tuleuova N, Lee JY, Lee J, Ramanculov E, Zern MA, et al. (2010) Using growth factor arrays and micropatterned co-cultures to induce hepatic differentiation of embryonic stem cells. Biomaterials 31: 9221-9231.

90. Nishiofuku M, Yoshikawa M, Ouji Y, Saito K, Moriya K, et al. (2011) Modulated differentiation of embryonic stem cells into hepatocyte-like cells by coculture with hepatic stellate cells. J Biosci Bioeng 111: 71-77.

91. Matsumoto K, Yoshitomi H, Rossant J, Zaret KS (2001) Liver organogenesis promoted by endothelial cells prior to vascular function. Science 294: 559-563.

92. Flaim CJ, Chien S, Bhatia SN (2005) An extracellular matrix microarray for probing cellular differentiation. Nat Methods 2: 119-125.

93. Matsumoto K, Mizumoto H, Nakazawa K, ljima H, Funatsu K, et al. (2008) Hepatic differentiation of mouse embryonic stem cells in a three-dimensional culture system using polyurethane foam. J Biosci Bioeng 105: 350-354.

94. Lee JY, Tuleuova N, Jones CN, Ramanculov E, Zern MA, et al. (2009) Directing hepatic differentiation of embryonic stem cells with protein microarray-based co-cultures. Integr Biol (Camb) 1: 460-468.

95. Li L, Sharma N, Chippada U, Jiang X, Schloss R, et al. (2008) Functiona modulation of ES-derived hepatocyte lineage cells via substrate compliance alteration. Ann Biomed Eng 36: 865-876.

96. Amimoto N, Mizumoto H, Nakazawa K, ljima H, Funatsu K, et al. (2011)
Hepatic differentiation of mouse embryonic stem cells and induced pluripoten stem cells during organoid formation in hollow fibers. Tissue Eng Part A 17 2071-2078.

97. Mizumoto H, Aoki K, Nakazawa K, ljima H, Funatsu K, et al. (2008) Hepatic differentiation of embryonic stem cells in HF/organoid culture. Transplant Proc 40: 611-613

98. Liu T, Zhang S, Chen X, Li G, Wang Y (2010) Hepatic differentiation of mouse embryonic stem cells in three-dimensional polymer scaffolds. Tissue Eng Part A 16: 1115-1122.

99. Farzaneh Z, Pournasr B, Ebrahimi M, Aghdami N, Baharvand H (2010) Enhanced functions of human embryonic stem cell-derived hepatocyte-like cells on three-dimensional nanofibrillar surfaces. Stem Cell Rev 6: 601-610.

100.Fang S, Qiu YD, Mao L, Shi XL, Yu DC, et al. (2007) Differentiation of embryoid-body cells derived from embryonic stem cells into hepatocytes in alginate microbeads in vitro. Acta Pharmacol Sin 28: 1924-1930.

101. Haque A, Hexig B, Meng Q, Hossain S, Nagaoka M (2011) The effect of recombinant E-cadherin substratum on the differentiation of endoderm-derived hepatocyte-like cells from embryonic stem cells. Biomaterials 32: 2032-2042.

102. Huang $P$, He Z, Ji S, Sun H, Xiang D, et al. (2011) Induction of functional hepatocyte-like cells from mouse fibroblasts by defined factors. Nature 475 386-389.

103. Sekiya S, Suzuki A (2011) Direct conversion of mouse fibroblasts to hepatocyte-like cells by defined factors. Nature 475: 390-393.

104. Shafritz DA, Oertel M (2011) Model systems and experimental conditions that lead to effective repopulation of the liver by transplanted cells. Int J Biochem Cell Biol 43: 198-213.

105. Sandgren EP, Palmiter RD, Heckel JL, Daugherty CC, Brinster RL, et al. (1991) Complete hepatic regeneration after somatic deletion of an albuminplasminogen activator transgene. Cell 66: 245-256.

106. Rhim JA, Sandgren EP, Degen JL, Palmiter RD, Brinster RL (1994) Replacement of diseased mouse liver by hepatic cell transplantation. Science 263: 1149-1152.

107. Weglarz TC, Degen JL, Sandgren EP (2000) Hepatocyte transplantation into diseased mouse liver. Kinetics of parenchymal repopulation and identification of the proliferative capacity of tetraploid and octaploid hepatocytes. Am J Pathol 157: 1963-1974.

108. Grompe M, Lindstedt S, al-Dhalimy M, Kennaway NG, Papaconstantinou J, e al. (1995) Pharmacological correction of neonatal lethal hepatic dysfunction in a murine model of hereditary tyrosinaemia type I. Nat Genet 10: 453-460.

109. Overturf K, Al-Dhalimy M, Tanguay R, Brantly M, Ou CN, et al. (1996) Hepatocytes corrected by gene therapy are selected in vivo in a murine mode of hereditary tyrosinaemia type I. Nat Genet 12: 266-273.

110. Azuma H, Paulk N, Ranade A, Dorrell C, Al-Dhalimy M, et al. (2007) Robust expansion of human hepatocytes in Fah-/-/Rag2-/-/I2rg-/- mice. Nat Biotechnol 25: 903-910

111. Bissig KD, Le TT, Woods NB, Verma IM (2007) Repopulation of adult and neonatal mice with human hepatocytes: a chimeric animal model. Proc Nat Acad Sci USA 104: 20507-20511.

112. Mercer DF, Schiller DE, Elliott JF, Douglas DN, Hao C, et al. (2001) Hepatitis $C$ virus replication in mice with chimeric human livers. Nat Med 7: 927-933.

113. He ZY, Deng L, Li YF, Xiang D, Hu JK, et al. (2012) Murine embryonic stem cell-derived hepatocytes correct metabolic liver disease after serial liver repopulation. Int J Biochem Cell Biol 44: 648-658.

114. Haridass D, Yuan Q, Becker PD, Cantz T, Iken M, et al. (2009) Repopulation efficiencies of adult hepatocytes, fetal liver progenitor cells, and embryonic stem cell-derived hepatic cells in albumin-promoter-enhancer urokinase-type plasminogen activator mice. Am J Pathol 175: 1483-1492.

115. Basma H, Soto-Gutiérrez A, Yannam GR, Liu L, Ito R, et al. (2009) Differentiation and transplantation of human embryonic stem cell-derived hepatocytes. Gastroenterology 136: 990-999.

116. Heo J, Factor VM, Uren T, Takahama Y, Lee JS, et al. (2006) Hepatic precursors derived from murine embryonic stem cells contribute to regeneration of injured liver. Hepatology 44: 1478-1486.

117. Chang HM, Liao YW, Chiang CH, Chen YJ, Lai YH, et al. (2012) Improvement 
Citation: Han S, Bourdon A, Hamou W, Dziedzic N, Goldman O, et al. (2012) Generation of Functional Hepatic Cells from Pluripotent Stem Cells. J Stem Cell Res Ther S10:008. doi:10.4172/2157-7633.S10-008

Page 11 of 11

of Carbon Tetrachloride-Induced Acute Hepatic Failure by Transplantation of Induced Pluripotent Stem Cells without Reprogramming Factor c-Myc. Int $J$ Mol Sci 13: 3598-3617.

118. Teratani T, Yamamoto H, Aoyagi K, Sasaki H, Asari A, et al. (2005) Direct hepatic fate specification from mouse embryonic stem cells. Hepatology 41 : 836-846.

119. Li HY, Chien Y, Chen YJ, Chen SF, Chang YL, et al. (2011) Reprogramming induced pluripotent stem cells in the absence of c-Myc for differentiation into hepatocyte-like cells. Biomaterials 32: 5994-6005.

120. Bandi S, Cheng K, Joseph B, Gupta S (2012) Spontaneous origin from human embryonic stem cells of liver cells displaying conjoint meso-endodermal phenotype with hepatic functions. J Cell Sci 125: 1274-1283.

121. Duan Y, Catana A, Meng Y, Yamamoto N, He S, et al. (2007) Differentiation and enrichment of hepatocyte-like cells from human embryonic stem cells in vitro and in vivo. Stem Cells 25: 3058-3068

122. Kajiwara M, Aoi T, Okita K, Takahashi R, Inoue H, et al. (2012) Donordependent variations in hepatic differentiation from human-induced pluripotent stem cells. Proc Natl Acad Sci USA 109: 12538-12543.
123. Kim K, Doi A, Wen B, Ng K, Zhao R, et al. (2010) Epigenetic memory in induced pluripotent stem cells. Nature 467: 285-290.

124. Polo JM, Liu S, Figueroa ME, Kulalert W, Eminli S, et al. (2010) Cell type of origin influences the molecular and functional properties of mouse induced pluripotent stem cells. Nat Biotechnol 28: 848-855.

125. Kim K, Zhao R, Doi A, Ng K, Unternaehrer J, et al. (2011) Donor cell type can influence the epigenome and differentiation potential of human induced pluripotent stem cells. Nat Biotechnol 29: 1117-1119.

126. Bar-Nur O, Russ HA, Efrat S, Benvenisty N (2011) Epigenetic memory and preferential lineage-specific differentiation in induced pluripotent stem cells derived from human pancreatic islet beta cells. Cell Stem Cell 9: 17-23.

127. Ghodsizadeh A, Taei A, Totonchi M, Seifinejad A, Gourabi H, et al. (2010) Generation of liver disease-specific induced pluripotent stem cells along with efficient differentiation to functional hepatocyte-like cells. Stem Cell Rev 6: $622-632$.

128. Shiraki N, Yamazoe T, Qin Z, Ohgomori K, Mochitate K, et al. (2011) Efficient differentiation of embryonic stem cells into hepatic cells in vitro using a feederfree basement membrane substratum. PLoS One 6: e24228.
This article was originally published in a special issue, Embryonic and Induced Pluripotent Stem Cells handled by Editor(s). Dr. Jianlong Wang, Mount Sinai School of Medicine, United States 